\title{
Reproductive System Hemorrhage
}

National Cancer Institute

\section{Source}

National Cancer Institute. Reproductive System Hemorrhage. NCI Thesaurus. Code C79472.

Bleeding originating in the organs and tissue that aid in reproduction. 